TITLE:

\title{
Chemical and Biological Remediation of CCA-Treated Waste Wood
}

$\operatorname{AUTHOR}(S):$

KARTAL, S. Nami; IMAMURA, Yuji

CITATION:

KARTAL, S. Nami ...[et al]. Chemical and Biological Remediation of CCA-Treated Waste Wood. Wood research : bulletin of the Wood Research Institute Kyoto University 2003, 90 : 111-115

ISSUE DATE:

2003-09-30

URL:

http://hdl.handle.net/2433/53099

RIGHT: 
Review Article

\title{
Chemical and Biological Remediation of CGA-Treated Waste Wood
}

\author{
S. Nami Kartal ${ }^{* 1,2}$ and Yuji Imamura* ${ }^{2}$ \\ (Received May 31, 2003)
}

\begin{abstract}
Since common disposal options such as landfill and incineration for chromated copper arsenate CGA-treated waste wood are becoming more unacceptable, there is a need to develop alternative technologies to use CCA-treated waste wood as a potential fiber source. Chemical and biological remediations of CCA-treated waste wood are thought to be environmentally acceptable. This paper reviews the ability of chemical and microbial processes to remove chromium, copper, and arsenic elements from CGA-treated waste wood. Some researchers have explored chemical extraction using various inorganic and organic acids. Depending on several parameters, such as concentration, time, temperature, $\mathrm{pH}$, particle size, etc., chemical extraction was found to be effective in removing much of the CCA from treated wood or contaminated wastes. On the other hand, bioremediation using bacteria and fungi is another possible method for removal of heavy metals from treated wood since some bacteria and fungi are extremely tolerant to toxic metals. Some copper tolerant fungi can remove some of the arsenic and chromium as well as copper. In addition, some metal leaching bacteria can be used effectively to extract concentrated heavy metal ions from treated wood.
\end{abstract}

Keywords: CGA wood preservative, treated waste wood, chemical extraction, microbial processes, bioremediation, detoxification, organic acid

\section{Introduction}

Chromated copper arsenate (CCA) has been a major water-borne wood preservative for more than 50 years for many applications. Chromium, copper, and arsenic elements of CGA wood preservative are stabilized in the wood by means of a number of chemical reactions called fixation. Chromium plays a role in the fixation reactions, while copper and arsenic are important in preservative efficacy due to their toxicity to wood degrading organisms. Depending on the specific forms of chromium, copper, and arsenic, these elements might be more or less carcinogenic, mutagenic, and toxic to a wide range of animals and harmful to the environment as well. Although CCAtreated wood is generally not considered toxic waste, there is an increasing public concern about environmental contamination caused by GCA-treated wood removed from service. The main reason for the concerns about CCAtreated waste wood is possible release of chromium, copper, and arsenic elements. Some of these elements can be released or leached from treated wood during managing spent CCA-treated wood such as reusing, recycling, landfilling, or burning. Remediation of CCA-treated wood before management options for treated wood can decrease concerns about environmental pollution and also the safety of the workers involved in the management of CGA-treated waste wood. This paper reviews recent advances and achievements on the removal of chromium, copper, and arsenic elements from CCA-treated waste wood by chemical and biological extraction.

${ }^{* 1}$ Visiting Scientist from Istanbul University of Turkey at Wood Reseach Institute.

*2 Laboratory of Deterioration Control.

\section{Quantity of CCA-treated waste wood}

Cooper ${ }^{1)}$ has recently reported that the volume of CCAtreated waste wood to be removed from service will increase significantly in the next two decades as a result of the historical use of CGA wood preservatives for residential construction. McQueen and Stevens ${ }^{2)}$ estimated that quantity of CCA-treated wood removed from service would increase to $12 \times 10^{6} \mathrm{~m}^{3}$ by 2004 in the USA. Although CCA wood preservatives will be phased out for residential applications in the USA by 2004, based on a 30-year average service life of CCA-treated wood, amount of CGAtreated wood is expected to increase each year. In Canada, on the other hand, the volume of spent CCAtreated wood will increase to $2.5 \times 10^{6} \mathrm{~m}^{3}$ by $2020^{1)}$.

Disposal of CGA-treated wood is also a growing problem in a number of European countries. The total amount of waste wood, for example, is around $3-4 \times 10^{6}$ tons per year of which $2.1-2.4 \times 10^{6}$ tons contains toxic components such as wood preservatives in Germany and France ${ }^{3)}$. A recent study by Stalker ${ }^{4}$ showed that similar restrictions on CGA wood preservatives would be present in some European countries and Europe would have adopted a uniform policy over CCA wood preservatives by 2004 . $\mathrm{He}$ also stated that GCA wood preservative might remain important in just a few equatorial and southern hemisphere countries in next 10 years ${ }^{4}$.

\section{Options for the disposal of CCA-treated waste wood}

A general hierarchic managing system for treated waste wood was defined by Cooper (Fig. 1) ${ }^{1)}$. In this hierarchic system, each option has its own specific importance. However, removal of chromium, copper, and arsenic elements from CCA-treated waste wood before some options such as recycling, physical treatments (lique- 


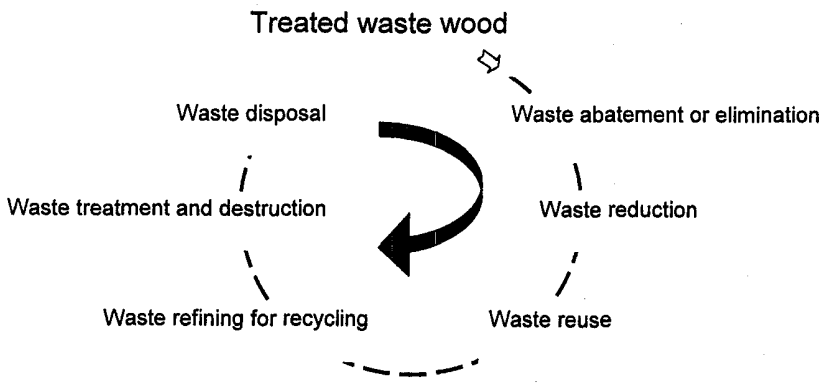

Fig. 1. Hierarchic managing options for treated waste wood.

faction, incineration, pyrolysis, etc.), and disposal (landfilling) will help alleviate potential soil and groundwater contamination in the landfills and airpollution caused by toxic gases and fumes ${ }^{5,6)}$. In addition, CGA-treated waste wood can be used for use in wood-based composites following extraction or bioremediation processes to remove toxic heavy metals since the quality and cleanliness of the wood furnish affects bonding properties of the wood particles ${ }^{1)}$. According to the hierarchic systems by Cooper ${ }^{1)}$, removal of heavy metals from treated wood especially before waste refining for recycling, waste treatment and destruction, and waste disposal will be essential for acceptance of CGA-treated waste by the manufacturers and public.

\section{Removal of CCA elements from treated wood}

\subsection{Chemical extraction of CCA-treated wood}

In chemical extraction, some factors are important in the removal of elements. Diffusion of extracting chemical to the wood, reaction of the chemical with the heavy metals, wood particle size, concentration of extracting chemical, $\mathrm{pH}$, temperature, extraction duration, mechanical shaking or solid state extraction are important factors in the extraction of treated waste wood ${ }^{5-7)}$. Solvent extraction of CGA-treated waste wood before bioremediation in dual remediation processes is considered efficacious in applying bioremediation process that is sensitive to high concentrations of copper, chromium, and arsenic elements in treated wood ${ }^{6)}$.

The objective of chemical extraction of CCA-treated waste wood is to form water-soluble compounds from the water-insoluble GCA compounds fixed to the wood components such as lignin and carbohydrates during fixation reactions ${ }^{6)}$. Kartal and Clausen ${ }^{8)}$ and Kartal and Clausen ${ }^{9}$ stated that exposure of CCA-treated wood to acid extraction can reverse the CGA fixation process thereby converting CGA elements into their water-soluble form. Several researchers have studied acid extraction, one of the most extensively used methods, to remove of CGA components ${ }^{5,6,8-24,25)}$. These studies suggested the feasibility of many organic acids, such as citric, acetic, formic, oxalic, ethylenediaminetetracetic (EDTA), fumaric, tartaric, gluconic, and malic, and mineral acids, such as sulphuric, hydrochloric, nitric, and phosphoric acids can remove copper, chromium, and arsenic elements.

On the other hand, Kazi and Cooper ${ }^{16)}$ extracted effectively most of CCA components from treated wood using hydrogen peroxide. In addition, some deck brighteners and washes containing sodium hypochlorite and sodium percarbonate were shown to be effective in the leaching of CGA elements ${ }^{25}$. Laboratory studies showed that high concentrations of humic acid increased the leaching of copper and chromium from CGA-treated wood $^{26)}$.

Recent studies have concentrated on organic acid extraction of CGA-treated waste wood. Some works showed that the removal of copper, chromium, and arsenic from GCA-treated wood waste increased significantly during oxalic acid extraction because oxalic acid functions not only as a chelating agent to sequester metal ions but also to reduce the $\mathrm{pH}$ thus providing acid conditions for remediation (Table 1$)^{6,8,9,17,19,20,23,27)}$. On the other hand, EDTA and nitrilotriacetic acid (NTA), other

Table 1. Percentage removal of CCA-elements from treated wood using some organic acids

\begin{tabular}{|c|c|c|c|c|c|c|c|}
\hline $\mathrm{Ac}$ & & Extraction & Wood source & & & & Literature \\
\hline Oxalic acid & $1 \%$ & $24 \mathrm{~h}$ & Sawdust & 81 & 62 & 89 & Clausen and Smith 1998 \\
\hline Oxalic acid & $1 \%$ & $24 \mathrm{~h}$ & Chips & 16 & 14 & 42 & Clausen and Smith 1998 \\
\hline Oxalic acid & $1 \%$ & $24 \mathrm{~h}$ & Steam exploded chips & 73 & 1 & 37 & Glausen and Smith 1998 \\
\hline Oxalic acid & $1 \%$ & $24 \mathrm{~h}$ & Wafers & 20 & 40 & 80 & Glausen 2000 \\
\hline Oxalic acid & $1 \%$ & $24 \mathrm{~h}$ & Sawdust & 61 & 41 & 75 & Kartal and Kose 2003 \\
\hline Oxalic acid & $1 \%$ & $24 \mathrm{~h}$ & Chips & 45 & 21 & 50 & Kartal and Kose 2003 \\
\hline Oxalic acid & $1 \%$ & $18 \mathrm{~h}$ & Chips & 23 & 65 & 74 & Kartal and Clausen 2001 \\
\hline Oxalic acid & $1 \%$ & $18 \mathrm{~h}$ & Chips & 52 & 0 & 59 & Clausen et al. 2001 \\
\hline Oxalic acid & $1 \%$ & $18 \mathrm{~h}$ & Chips & 55 & 60 & 75 & Son et al. 2003 \\
\hline Citric acid & $\mathrm{pH}: 3.5$ & $24 \mathrm{~h}$ & Chips & 42 & 42 & 38 & Shiau et al. 2000 \\
\hline Citric acid & $\mathrm{pH}: 3.5$ & $24 \mathrm{~h}$ & Steam exploded chips & 76 & 8 & 45 & Shiau et al. 2000 \\
\hline Acetic acid & $\mathrm{pH}: 3.5$ & $24 \mathrm{~h}$ & Chips & 31 & 32 & 30 & Shiau et al. 2000 \\
\hline Acetic acid & $\mathrm{pH}: 3.5$ & $24 \mathrm{~h}$ & Steam exploded chips & 69 & 0 & 37 & Shiau et al. 2000 \\
\hline EDTA & $1 \%$ & $24 \mathrm{~h}$ & Sawdust & 93 & 36 & 38 & Kartal 2003; Kartal and Kose 2003 \\
\hline EDTA & $1 \%$ & $24 \mathrm{~h}$ & Chips & 60 & 13 & 25 & Kartal 2003; Kartal and Kose 2003 \\
\hline NTA & $1 \%$ & $24 \mathrm{~h}$ & Sawdust & 89 & 35 & 33 & Kartal and Kose 2003 \\
\hline NTA & $1 \%$ & $24 \mathrm{~h}$ & Ghips & 9 & 45 & 22 & Kartal and Kose 2003 \\
\hline Oleic acid & $\mathrm{pH}: 2$ & $24 \mathrm{~h}$ & Wood blocks & 67 & 63 & 81 & Gezer et al. 2003 \\
\hline
\end{tabular}


chelating agents like oxalic acid, were found to be effective in copper removal from CCA-treated wood. EDTA and NTA extraction was the key to unfix copper and was also used effectively in conjunction with oxalic acid for removal all CCA-components from treated wood $(\text { Table } 1)^{23}$. In addition, oleic acid was found to be effective in copper, chromium, and arsenic removal and removal efficiency increased at lower $\mathrm{pH}$ levels than 2.5 in a recent study $(\text { Table } 1)^{24)}$.

In acid extraction, temperature, acid concentration and other variables can be optimized to minimize remediation time ${ }^{1)}$. On the other hand, with dual remediation process, it is possible to increase removal efficiency with selecting proper solvents for any specific heavy metals.

As reviewed above, laboratory and semi-pilot plant scale trials indicated the feasibility of chemical extraction using various kinds of acids. However, few commercial plants have been operating.

\subsection{Bioremediation of CGA-treated waste wood using bacteria and fungi}

Bioremediation of CGA-treated wood involves complex biological, chemical, and physical reactions which are able to immobilize or transform toxic heavy metals. In fact, it is difficult to remove heavy metals from treated wood because they are fixed to the wood components during chemical fixation reactions. The use of microorganisms for remediation of GGA-treated wood has been receiving an increasing attention for a long time because of low cost and high efficiency compared to chemical extraction processes. Many microorganisms including bacteria and fungi can be used effectively in removing heavy metals from CCA-treated wood. Many organisms have been identified that are capable of oxidizing or reducing chromium, copper, and arsenic to water-soluble forms, which can be then removed from treated wood ${ }^{7)}$.

The bacterial mechanism is the active efflux pumping the toxic heavy metal out of the cell or the enzymatic detoxification converting a toxic ion into a less toxic or less available metal ion ${ }^{28)}$. Greaves ${ }^{29)}$ also proposed that bacterial capsules and slime layers complex with elements such as copper and lock up the toxic metal when it is released in small quantities by bacterial enzymes ${ }^{30)}$.

Clausen ${ }^{31)}$ isolated several bacteria capable of removing copper, chromium, and arsenic from treated wood. Of 28 different bacterial species, three isolates, Acinetobacter calcoaceticus FN02, Aureobacterium esteroaromaticum VV03, and Klebsiella oxytoca CC08 were able to remove $98 \%$ chromium which is the most difficult component of CGA wood preservative to release from treated wood. On the other hand, copper removal was $93 \%$ with Bacillus licheniformis CC01. Clausen and Smith ${ }^{6)}$ showed that gram-positive spore-forming bacteria from the genus Bacillus are commonly isolated from treated wood and tolerant of copper levels in CCA-treated wood. In the study by Clausen and Smith ${ }^{6)}$, CGA-treated sawdust was inoculated with liquid culture of $B$. licheniformis for 10 days. Exposure to the bacterium removed $91 \%$ copper, $45 \%$ arsenic, and 15\% chromium from CGA-treated sawdust. Moreover, pre-treatments (steaming or acid extraction) could enhance bacterial remediation of CGA-treated wood $^{6,8,9,17)}$. Kartal and Clausen ${ }^{8)}$, Kartal and Clausen $^{9)}$, and Clausen et al. ${ }^{17)}$ showed that oxalic acid extraction followed by bacterial fermentation with $B$. licheniformis removed about $62 \% \mathrm{CuO}, 79 \% \mathrm{CrO}_{3}$, and $90 \% \mathrm{As}_{2} \mathrm{O}_{5}$ of initial amounts of these elements in CCAtreated wood. Similar results were obtained when CCAtreated wood exposed to steaming before bacterial fermentation process ${ }^{6)}$. Bacillus ssp. are ubiquitous in soils and are capable of producing pectinolytic and cellulolytic enzyme systems that may assist in releasing copper and arsenic from wood ${ }^{6,8,9)}$. Cole and Clausen ${ }^{32)}$ stated that $B$. licheniformis is able to accumulate copper and chromium intracellulary. Daniel et al. ${ }^{33)}$ examined copper accumulations as dense particles within the nuclear region of tunneling bacteria. Felton and DeGroot ${ }^{7)}$ stated that removal of arsenic from CCA-treated wood with bacteria results in a complex relationship between bacteria oxidizing and reducing copper and chromium and the complexes formed by their metabolites.

In addition to bacteria, fungi play an important role in remediation of CCA-treated wood and heavy metals can be transformed by the enzyme systems of fungi. In some cases, fungus cell structure shows ability to absorb heavy metals from several media containing heavy metal ions. Fungal remediation of CCA-treated wood can be achieved by selected fungi having catabolic activity and ability to transform the toxic compounds and bring the concentration to lower levels ${ }^{34)}$. At the same time, remediation conditions must be made conducive to microbial growth or activity supplying inorganic nutrients, oxygen, moisture content, suitable temperature, source of carbon and energy ${ }^{34,35)}$. Felton and DeGroot ${ }^{7)}$ stated that because chromium, copper, and arsenic cannot be transformed into nontoxic forms, the objective of remediation of CCA-treated wood with fungi is to reduce or oxidize these elements to water-soluble forms. Ghanges in valance state and alkylation are the main routes in transformation of toxic ions. Gomes $e^{2}$ al. ${ }^{36)}$ also pointed out that fungal tolerance to heavy metals can be due to diverse mechanism such as accumulation or biosorption of heavy metals by cell wall components and extracellular materials, chelation or precipitation by secreted metabolites such as enzyme or acid, and complexation with inner low molecular weight proteins.

Fungi and bacteria can be used as biosorbents for heavy metals ${ }^{37)}$. The metal uptake process is complex and dependent on the chemistry of the metal ions, specific surface properties of the organisms, cell physiology and physical conditions such as $\mathrm{pH}$, temperature, and metal concentration of medium. Fungal biosorption of heavy metals on fungi occurs as a result of ionic interactions and complex formation between metal ions and functional groups present on the fungal cell surface. The functional groups in the biosorption of heavy metals are phosphate, carboxyl, amine, and amido groups ${ }^{38)}$. The use of microbial biomass for the biosorption of metals from solid and aqueous wastes has been proved to be a promising alternative to remediation strategies. Fungus biomass belonging to the genera Rhizopus, Penicillum and Aspergillus were shown to be potential for the removal of varying heavy metals from aqueous solutions ${ }^{36,39,40)}$.

Previous studies on the chemical and biological remediation of CCA-treated wood showed that the type of chemicals, fungi, and bacteria has an effect on remediation 
and final concentrations of CCA in the waste wood ${ }^{41,42)}$. The removal of copper, chromium, and arsenic from CCAtreated wood increased significantly during oxalic acid extraction $^{8,9,17,19,20)}$. Oxalic acid can be produced in a biotechnological process because some fungi are capable to secrete oxalic acid at several concentrations into the culture broth $^{41)}$. Oxalate is a small agent penetrating into the cell wall structure of wood and may function in conjunction with metals in the initiations of depolymerization of wood cell components. Oxalate produced by brown-rot fungi show ability to complex iron and other metal ions. The properties of these chelators suggest their applicability to the remediation of treated waste wood containing heavy metal ions. Fungi evolve several mechanisms to prevent cellular contact with metals. Extracellular complexation mechanism which prevents cellular contact with metals is the ability of the fungi to produce organic acid such as oxalic acid. For instance, the tolerance of some decay fungi to copper element has been linked to amount of oxalic acid produced by the fungi ${ }^{6,22,41)}$. Preservative-tolerant organisms are of great interest from two different perspectives. Mechanism of tolerance would allow development of new wood preservatives and these organisms could be used for the bioremediation, biodeterioration, and bioconversion of preservative-treated waste wood $^{43)}$.

The microbial production of organic acids is of growing interest in the treatment of pollution and remediation of treated wood. In most fungi, leaching of heavy metals is mediated by the production of organic acids, which provide a source of protons and metal complexing organic acid ions ${ }^{44)}$. Studies by Kartal and Imamura ${ }^{21)}$ and Kartal et al. ${ }^{41)}$ showed that the brown-rot fungus Fomitopsis palustris (Berkeley et Curtis) Murrill (TYP 6137) remediation of CCA-treated sawdust for 10 days removed about $72 \%$ copper, $87 \%$ chromium, and $100 \%$ arsenic, while $50 \%$ copper, $69 \%$ chromium, and $85 \%$ arsenic were removed from treated sawdust after 10-days remediation by another brown-rot fungus Laetiporus sulphureus (Bulliard ex Fries) Bondarcev et Singer (IFO 30745). The percentage copper, chromium, and arsenic by brown-rot fungus Coniphora puteana (Schum ex Fries) Karsten (COP 6275 ) remediation was about $67 \%, 19 \%$, and $18 \%$, respectively. In these studies, oxalic acid produced by the fungi during fermentation was used for the removal of metal elements via bioleaching ${ }^{21,41)}$. These studies showed that the ability of fungi, which are able to produce high amounts of oxalic acid to remove heavy metals from CCA-treated wood, can be considered as potential biological agents for the acid extraction of treated wood. A similar study by Son et al. ${ }^{27)}$ also showed that remediation of CGA-treated wood by $F$. palustris grown in a bioreactor resulted in $61 \%$ copper, $72 \%$ chromium, and $59 \%$ arsenic removal.

Other studies suggested investigated the potential of the fungus Aspergillus niger to remove copper, chromium, and arsenic from waste wood treated with CCA wood preservative ${ }^{21,42)}$. A. niger was cultivated in carbohydrates media in order to produce large quantities of oxalic acid. Bioremediation of CGA-treated wood in the second stage was performed through leaching of heavy metals with oxalic acid occurred during the first stage.
Exposure of GCA-treated chips to A. niger for 10 days decreased $97 \%$ arsenic. In addition, $A$. niger fermentation removed $49 \%$ copper and $55 \%$ chromium from CCAtreated chips.

Although white-rot fungi are usually less tolerant to copper-based wood preservatives than brown-rot fungi, some white-rot fungi are able to degrade wood treated with copper-containing preservatives ${ }^{45)}$. Metal ions are involved in the decomposition of cellulose and hemicellulose by brown-rot fungi, whereas in white-rot fungi, copper and manganese directly participate in the process of lignin degradation ${ }^{46)}$. White-rot fungi can concentrate metals taken up from substrate in their mycelia via biosorption ${ }^{35,46)}$. White-rot fungi growing on wood can accumulate copper element from wood in their fruit bodies. On the other hand, enzymes such as hemicellulolytic degrading and ligninolytic enzymes secreted by white-rot fungi play a role in removal or degradation of heavy metals.

The white-rot fungus Trametes versicolor is known to be less tolerant against CGA wood preservative than the brown-rot fungus Gloeophyllum trabeum ${ }^{9}$. Jusoh and Kamdem ${ }^{47)}$ also showed that lower GCA retentions levels were necessary to prevent the growth of the white-rot fungus Irpex lacteus and $T$. versicolor compared to the brownrot growth. Knowledge on the interaction of heavy metal ions with enzyme systems of white-rot fungi and the application of fungal mycelia for remediation is important for developing novel remediation technologies for treated wood.

\section{Concluding remarks}

Exposure of CGA-treated waste wood to acid extraction may reverse the CGA fixation reactions because high acidic conditions play a role in releasing CGA elements from treated wood. On the other hand, pre-chemical extraction of CGA elements from treated wood seems to efficiently work for the subsequent bioremediation processes in case of high concentrations of toxic heavy metals in treated wood ${ }^{7}$. For successful bioremediation, processes are highly dependent on selection of proper organisms and process conditions for degradation to occur. Bioremediation of CGA-treated waste wood offers several advantages over other options for treated waste wood such as landfilling, burning, etc in terms of environmental soundness. However some heavy metals may not be removed by bioremediation using a specific organism and microbial metabolism of toxic heavy metals may result in toxic compounds. Because of these complexities, successful bioremediation can be achieved with several disciplines as microbiology, engineering, ecology, geology, and chemistry ${ }^{48}$.

\section{Acknowledgements}

This paper was prepared during the first author's visit to Wood Research Institute, Kyoto University as a visiting scientist under JSPS (Japanese Society for the Promotion of Science) Post-Doctoral Research Program.

\section{References}

1) P.A. Cooper: Proceedings of American Wood Preservers' Association (AWPA) 99th Annual Meeting, 17pp. (2003). 
Kartal et al.: Chemical and Biological Remediation of CCA-Treated Waste Wood

2) J. McQueen and J. Stevens : For. Prod. J., 48(11/12), 86-90 (1998).

3) L. Helsen, E.V.D. Bulck and J.S. Hery : Waste Manage., 18, 571-578 (1998)

4) I.N. Stalker: Proceedings, American Wood Preservers' Association (AWPA) 99th Annual Meeting, 11pp. (2003).

5) S.N. Kartal: Waste Manage., in press (2003).

6) G.A. Clausen and R.L. Smith : J. of Ind. Microbiol. Biot., 20, 251-257 (1998).

7) G.C. Felton and R.G. DeGroot: For. Prod. J., 46(7/8), $37-46$ (1996).

8) S.N. Kartal and Clausen : International Research Group on Wood Preservation, Document No. IRG/WP/01-50170 (2001).

9) S.N. Kartal and C.A. Glausen : Int. Biodeter. Biodegr. 47, 183-191 (2001).

10) A. Honda, Y. Kanjo, A. Kimoto, K. Koshi and S. Kashiwazaki : Int. Res. Group on Wood Pres., Document No. IRG/WP/91-3651 (1991).

11) J. KIм and G. KIm: International Research Group on Wood Preservation, Document No. IRG/WP/93-5004 (1993).

12) I. Stephan, H. Mimz and R.-D. Peek : International Research Group on Wood Preservation, No. IRG/WP/93-50012 (1993).

13) I. Stephan, H. Leithoff and R.-D. Peek: Mater. Organismen., 30, 179-200 (1996).

14) E. Pasek : Proceeding, CITW Life Cycle Assessment Workshop, pp. 76-104 (1994).

15) D.P. Kamdem, W. Ma, J. Zhang and J. Zyskowski: International Research Group on Wood Preservation, Document No. IRG/WP/98-50118 (1998).

16) F. KAzI and P.A. Cooper : Proceedings of Canadian Wood Preservers' Association 20th Annual Meeting (1999).

17) C.A. Glausen: Waste Manage. Res., 18, 485-488 (2000).

18) R.J. Shiau, R.L. Smith and B. Avellar: Wood Sci Technol., 34, 377-388 (2000)

19) C.A. Glausen GA, S.N. Kartal and J. Muehl: International Research Group on Wood Preservation, Document No. RG/WP/00-50146 (2000).

20) G.A. Glausen, S.N. Kartal and J. Muehl: For. Prod. J., 51, 61-64 (2001)

21) S.N. Kartal and Y. Imamura: Proceedings of International Conference on Forest Products, 30th Anniversary of the Korean Society of Wood Science and Technology (IAWPS2003), Daejon, Korea, 21-24 April 2003, 480-485 (2003).

22) S.N. Kartal, E. MuniR and Y. Imamura: Abstracts of the 53rd Annual Meeting of the Japan Wood Research Society, Fukuoka, Japan, 22-24 March 2003, Doc. No. Q231045 (2003).

23) S.N. Kartal and C. Kose: Holz Roh Werkst. (in press) (2003).
24) E.D. Gezer, U. Yildiz, S. Yildiz, E. Dizman and A. Temiz: International Research Group on Wood Preservation, Document No. IRG/WP/03-50202 (2003).

25) A. Taylor, P.A. Cooper and Y.T. Ung : For. Prod. J., 51, 69-72 (2001)

26) P.A. Cooper, D. Jeremic, J.L. TAylor, Y.T. Ung and F. KazI : For. Prod. J., 51(9), 73-77 (2001)

27) D.W. Son, D.H. LeE and G.H. KANG: Proceedings of International Conference on Forest Products, 30th Anniversary of the Korean Society of Wood Science and Technology (IAWPS2003), 1059-1064 (2003).

28) M. Mejare and L. Bulow: Trends in Biotechnol., 19(2), 67-73 (2001).

29) H. Greaves: Wood Sci. Technol., 5, 6-16 (1971).

30) C.A. Glausen : Int. Biodet. Biodegrad., 37, 101-107 (1996).

31) G.A. Glausen : Waste Manage. Res., 18, 264-268 (2000).

32) F.A. Gole and G.A. Glausen : Proceedings of Forest Products Society Conference on Use of Recycled Wood and Paper in Building Applications (1996).

33) G. Daniel, T. Nilsson and A.P. Singh : Can J. Microbial., 33, 943-948 (1987).

34) M. Alexander: Biodegradation and Bioremediation, Academic, New York (1994).

35) S.B. Pointing : Appl. Microbiol. Biotechnol., 57, 20-23 (2001).

36) N.G.M. Gomes, M.M. Figueira, E.R.S. Camargos, L.G.S.M. Hagler, J.C.T. Dias and V.R. Linardi: Biotechnol. Letters, 21, 487-490 (1999).

37) N. Goyal, S.C. Jain and U.C. BanerJe: Advances in Environmental Res., 7(2), 311-319 (2003).

38) A. Kapoor and T. Viraraghavan : Bioresource Technol., 61, 221-227 (1997)

39) A. Kapoor, T. Viraraghavan and D.R. Gullimore: Bioresource Technol., 60, 95-104 (1996).

40) K. Tsekova and S. Illieva : Appl. Microbiol. Biotechnol., 55, 636-637 (2001)

41) S.N. Kartal, E. Munir, T. Kakitani and Y. Imamura: $J$. Wood Science, (in press) (2003).

42) S.N. Kartal, T. Kakitani and Y. Imamura: Holz Roh Werkst., (in press) (2003).

43) A.M.F. Milagres, V. Arantes, C.L. Medeiros and A. Machuca: Enzyme Microb. Technol., 30, 562-565 (2002).

44) G.M. GadD: Current Opinion in Biotechnol., 11, 271-279 (2000).

45) M. Humar, M. Petria and F. Pohleven : Holz Roh Werkst., 59, 288-293 (2001).

46) P. Baldrian : Enzyme and Microbial. Technol., 32, 78-91 (2003).

47) I. Jusoh and D.P. Kamdem: Holzforschung, 55, 250-254 (2001).

48) R. Boopathy: Bioresource Technol., 74, 63-67 (2000). 